\title{
Hypouricemic Effects of Chrysanthemum indicum L. and Cornus officinalis on Hyperuricemia-Induced HepG2 Cells, Renal Cells, and Mice
}

\author{
Ok-Kyung Kim ${ }^{1}\left(\mathbb{D}\right.$, Jeong-Moon Yun ${ }^{2}$, Minhee Lee ${ }^{2} \mathbb{D}$, Dakyung Kim $^{2} \mathbb{D}$ and Jeongmin Lee ${ }^{2,3, *}$ \\ 1 Division of Food and Nutrition and Human Ecology Research Institute, Chonnam National University, \\ Gwangju 61186, Korea; 20woskxm@jnu.ac.kr \\ 2 Department of Medical Nutrition, Kyung Hee University, Yongin 17104, Korea; \\ moon1894@hanmail.net (J.-M.Y.); miniclsrn@khu.ac.kr (M.L.); k4kyung@naver.com (D.K.) \\ 3 Research Institute of Clinical Nutrition, Kyung Hee University, Seoul 02447, Korea \\ * Correspondence: jlee2007@khu.ac.kr; Tel.: +82-31-201-3838; Fax: +82-31-204-8119
}

Citation: Kim, O.-K.; Yun, J.-M.; Lee, M.; Kim, D.; Lee, J. Hypouricemic Effects of Chrysanthemum indicum $\mathrm{L}$. and Cornus officinalis on

Hyperuricemia-Induced HepG2 Cells, Renal Cells, and Mice. Plants 2021, 10, 1668. https://doi.org/10.3390/ plants10081668

Academic Editor: Adam Stebel

Received: 29 July 2021

Accepted: 12 August 2021

Published: 13 August 2021

Publisher's Note: MDPI stays neutral with regard to jurisdictional claims in published maps and institutional affiliations.

Copyright: (c) 2021 by the authors. Licensee MDPI, Basel, Switzerland. This article is an open access article distributed under the terms and conditions of the Creative Commons Attribution (CC BY) license (https:// creativecommons.org/licenses/by/ $4.0 /)$.

\begin{abstract}
Hyperuricemia, abnormally excess accumulation of uric acid, is caused by an imbalance between the production and excretion of uric acid and is a major cause of gout. We compared the effects of extracts from Chrysanthemum indicum L. (Ci) and Cornus officinalis Siebold and Zucc. (Co) on hyperuricemia, both individually and in combination (FSU-CC), using hypoxanthine-treated human liver cancer (HepG2) cells, primary mouse renal proximal tubule cells, and potassium oxonate induced hyperuricemic mice. The Ci contained $7.62 \mathrm{mg} / \mathrm{g}$ luteolin and $0 \mathrm{mg} / \mathrm{g}$ loganin, Co contained $0 \mathrm{mg} / \mathrm{g}$ luteolin and $4.90 \mathrm{mg} / \mathrm{g}$ loganin, and FSH-CC contained $3.95 \mathrm{mg} / \mathrm{g}$ luteolin and $2.48 \mathrm{mg} / \mathrm{g}$ loganin. We found that treatment with $\mathrm{Ci}, \mathrm{Co}$, and FSU-CC suppressed the activity of xanthine oxidase and mRNA expression of xanthine dehydrogenase while inducing an increase in the expression levels of the organic anion transporter 1 (OAT1) and organic anion transporter 3 (OAT3) proteins and a decrease in the expression levels of glucose transporter 9 (GLUT9) and urate transporter 1 (URAT1) proteins. Particularly, treatment and supplementation with FSU-CC showed stronger effects than those of supplementation with either $\mathrm{Ci}$ or Co alone. We observed that the excretion of creatinine and uric acid in the combination of $\mathrm{Ci}$ and $\mathrm{Co}$ was higher than that observed in their individual supplementations and was similar to that of the normal group. Therefore, our data suggest that a combination of $\mathrm{Ci}$ and $\mathrm{Co}$ may potentially be used for the development of effective natural anti-hyperuricemic functional foods.
\end{abstract}

Keywords: Chrysanthemum indicum L.; Cornus officinalis Siebold and Zucc.; hyperuricemia; uric acid

\section{Introduction}

Purines play important roles as the precursors of nucleic acids, DNA and RNA, promoting the growth, proliferation, and survival of all cells. Purine metabolism is regulated and maintained by the synthesis and degradation of purines, with uric acid being the final compound in purine catabolism [1]. Abnormally excess accumulation of uric acid, known as hyperuricemia, is caused by an imbalance between the production and excretion of uric acid [2]. Consumption of purine-rich and protein-rich foods and alcohol is directly associated with hyperuricemia, which is a major cause of gout due to the deposition of urate crystals in the soft tissues and joints [3]. Gout affects $<1$ to $6.8 \%$ of the population, and the prevalence of hyperuricemia and gout has been increasing over the years [4].

Uric acid is produced by the activities of xanthine oxidase and xanthine dehydrogenase, together referred to as "xanthine oxidoreductase", in the liver. Xanthine oxidoreductase catalyzes the oxidation of hypoxanthine to xanthine and later to uric acid $[5,6]$. Xanthine dehydrogenase is initially synthesized and can be converted to xanthine oxidase by reversible sulfhydryl oxidation or irreversible proteolysis [7]. During the production of 
uric acid, xanthine oxidase delivers electrons directly to molecular oxygen, thus generating the reactive oxygen species (ROS), including the superoxide anion $\left(\mathrm{O}_{2}{ }^{--}\right)$and hydrogen peroxide $\left(\mathrm{H}_{2} \mathrm{O}_{2}\right)$, which can further induce oxidative stress [8]. Approximately $75 \%$ of uric acid excretion occurs in the kidneys and approximately $25 \%$ occurs in the intestines. The circulating uric acid is filtered in the kidneys, and about $90 \%$ of the filtered load is usually reabsorbed in the nephrons [9]. Uric acid reabsorption occurs in the renal proximal tubules, facilitated by transporters such as glucose transporter 9 (GLUT9), urate anion transporter 1 (URAT1), and organic anion transporter 4 (OAT4), while uric acid excretion is facilitated by transporters such as organic anion transporter 1 (OAT1) and organic anion transporter 3 (OAT3). Maintaining the function of these uric acid transporters is important to prevent hyperuricemia [10,11].

In this study, we investigated the effects of Chrysanthemum indicum L. and Cornus officinalis Siebold and Zucc. on hyperuricemia in in vitro and in vivo models. C. indicum L., called Indian chrysanthemum, a member of the Compositae family, and C. officinalis Siebold and Zucc., a member of the Cornaceae family, have been reported to exhibit antiinflammatory and anticancer effects and possess antioxidant properties [12-14]. We compared the effects of treatment with extracts from C. indicum L. and C. officinalis Siebold and Zucc., both individually and in combination, on hypoxanthine-treated human liver cancer cells, primary mouse renal proximal tubule cells, and potassium oxonate induced hyperuricemic mice to develop agents for the prevention of hyperuricemia.

\section{Materials and Methods}

\subsection{Extract Preparation and HPLC}

Flowers of C. indicum L. were extracted using water for $8 \mathrm{~h}$ at $90^{\circ} \mathrm{C}$. The extract was filtered with Whatman paper No. 6 and concentrated in a rotary evaporator under reduced pressure. The concentrate was lyophilized (Ci) and stored at $-20{ }^{\circ} \mathrm{C}$ until further use. Fruits of $C$. officinalis Siebold and Zucc. were extracted using water for $8 \mathrm{~h}$ at $90^{\circ} \mathrm{C}$. The extract was filtered with Whatman paper No. 6 and concentrated in a rotary evaporator under reduced pressure. The extract was dried using hot air with dextrin $(50 \%)(\mathrm{Co})$ and stored at $-20^{\circ} \mathrm{C}$ until further use. $\mathrm{Ci}$ and $\mathrm{Co}$ were mixed in a ratio of $1: 2$ (FSH-CC) and stored at $-20^{\circ} \mathrm{C}$ until further use. Then, these extracts, $\mathrm{Ci}, \mathrm{Co}$, and $\mathrm{FSH}-\mathrm{CC}$, were analyzed for luteolin and loganin, separately, by high-performance liquid chromatography (HPLC) using an Agilent 1260 Infinity II HPLC system (Santa Clara, CA, USA).

\subsection{Cell Culture and Treatments}

The human liver cancer (HepG2) cells were obtained from the American Type Culture Collection (ATCC; Manassas, VA, USA). The cells were cultured in Dulbecco's minimal essential medium (DMEM; Hyclone Laboratories, Logan, UT, USA) supplemented with 10\% fetal bovine serum (FBS; Hyclone Laboratories), $100 \mathrm{mg} / \mathrm{L}$ penicillin-streptomycin, and $2 \mathrm{mmol} / \mathrm{L}$ glutamine (Hyclone Laboratories) at $37^{\circ} \mathrm{C}$ in a humid atmosphere of $5 \%$ carbon dioxide $\left(\mathrm{CO}_{2}\right)$.

To obtain the primary mouse renal proximal tubule cells, kidney was isolated from Balb/c mice (22-25 g, 6 weeks, male). The kidney was minced using Hank's balanced salt solution (HBSS) containing trypsin, with the addition of $1 \mathrm{mg} / \mathrm{mL}$ deoxyribonuclease (DNAse) and $2 \mathrm{mg} / \mathrm{mL}$ collagenase type I (Sigma-Aldrich, St. Louis, MO, USA). After $30 \mathrm{~min}$, the solution was passed through an 80-mesh and 1709-mesh sieve (Fisher Scientific, Pittsburgh, PA, USA) to remove the cell debris and glomeruli. Proximal tubule cells remained on the sieve filter and were collected by washing the sieve filter with HBSS. The proximal tubule cell suspension was centrifuged for $10 \mathrm{~min}$ at 1000 revolutions per minute (rpm) at $4{ }^{\circ} \mathrm{C}$, and the cell pellet was collected.

HepG2 cells and primary mouse renal proximal tubule cells were cultured with $\mathrm{Ci}$, $\mathrm{Co}$, and FSH-CC for $24 \mathrm{~h}$ and treated with $4 \mathrm{mM}$ hypoxanthine. After $2 \mathrm{~h}$, assays were performed to measure the activity of xanthine oxidase; mRNA expression of xanthine dehydrogenase; and the expression levels of OAT1, OAT3, GLUT9, and URAT1 proteins. 


\subsection{Animals}

The Institutional Animal Care and Use Committee of Kyung Hee University approved the protocol (KHGASP-20-410) for the use of animals in this study. The animals were cared for in accordance with the "Guidelines for Animal Experiments" established by the university.

Six-week-old male C57 black 6 (C57BL6) mice were purchased from SaeRon Bio (Uiwang, Korea) and housed in cages under automatically controlled temperature $\left(22 \pm 2{ }^{\circ} \mathrm{C}\right)$, humidity (about 50\%), and lighting (12:12-h light-dark cycle) conditions. The mice in the control group with normal diet were fed a commercial pelleted chow (AIN-93G rodent purified diet, Orient Bio, Korea) and water ad libitum. All the mice were randomly divided into eight groups of eight mice per group as follows: normal control (NC), control (C; hyperuricemia-induced mice), positive control (PC; hyperuricemia-induced mice with oral supplementation of allopurinol, xanthine oxidase inhibitor, $10 \mathrm{mg} / \mathrm{kg}$ body weight (b.w.)), Ci 300 (hyperuricemia-induced mice with oral supplementation of Ci, $300 \mathrm{mg} / \mathrm{kg}$ b.w.), Co 300 (hyperuricemia-induced mice with oral supplementation of $\mathrm{Co}, 300 \mathrm{mg} / \mathrm{kg}$ b.w.), FSH-CC 150 (hyperuricemia-induced mice with oral supplementation of FSH-CC, $150 \mathrm{mg} / \mathrm{kg}$ b.w.), FSH-CC 300 (hyperuricemia-induced mice with oral supplementation of FSH-CC, $300 \mathrm{mg} / \mathrm{kg}$ b.w.), and FSH-CC 600 (hyperuricemia-induced mice with oral supplementation of FSH-CC, $600 \mathrm{mg} / \mathrm{kg}$ b.w.). The extracted samples were orally administered for 21 days. To induce hyperuricemia, an intraperitoneal injection of $200 \mathrm{mg} / \mathrm{kg}$ b.w. potassium oxonate (Sigma-Aldrich Co, St. Louis, MO, USA) was given. After $2 \mathrm{~h}$, the mice's urine was collected and the mice were anesthetized with isoflurane.

\subsection{Levels of Uric Acid and Creatinine in the Urine and Serum}

Blood was centrifuged at $3000 \mathrm{rpm}$ for $10 \mathrm{~min}$ and the serum was separated. The levels of uric acid in the urine and serum were determined using the uric acid assay kits (BioVision Inc., Milpitas, CA, USA), while the levels of creatinine in the urine and serum were determined using the creatinine assay kit (BioVision Inc., Milpitas, CA, USA).

\subsection{Activity of Xanthine Oxidase}

The activity of xanthine oxidase was determined from the HepG2 cells in the culture medium and serum from mice using the Xanthine Oxidase Activity Assay Kit (SigmaAldrich Co, St. Louis, MO, USA).

\section{6. mRNA Expression of Xanthine Dehydrogenase}

mRNA was extracted from the HepG2 cells and liver tissues using the RNeasy Mini Kit (QIAGEN, MD, USA). Synthesis of complementary DNA (cDNA) using mRNA was performed using the iScript cDNA Synthesis Kit (Bio-Rad Laboratories, Inc., Hercules, CA, USA). Polymerase chain reaction (PCR) consisted of 40 cycles of denaturation $\left(95^{\circ} \mathrm{C}\right.$ for $15 \mathrm{~s})$, annealing $\left(58^{\circ} \mathrm{C}\right.$ for $\left.15 \mathrm{~s}\right)$, and extension $\left(72{ }^{\circ} \mathrm{C}\right.$ for $\left.30 \mathrm{~s}\right)$ using the SYBR Green PCR Master Mix (iQ SYBR Green Supermix; Bio-Rad Laboratories, Inc.) and the following primers: GAPDH (H) forward primer $5^{\prime}$-CCC CAC ACA CAT GCA CTT ACC- $3^{\prime}$, reverse primer $5^{\prime}$-TTG CCA AGT TGC CTG TCC TT-3'; xanthine dehydrogenase (H) forward primer 5'-ATT GGT GCT GTG GTT GCT-3' ${ }^{\prime}$, reverse primer $5^{\prime}$-TGT GAT AAT GGC TGG TAG TTC TTC; GAPDH (R) forward primer $5^{\prime}$-CAT GGC CTT CCG TGT TCC TA- ${ }^{\prime}$, reverse primer $5^{\prime}$-GCG GCA CGT CAG ATC CA-3'; xanthine dehydrogenase (R) forward primer $5^{\prime}$-TGC GAA GGA TGA GGT TAC T-3' ${ }^{\prime}$, reverse primer $5^{\prime}$-GGA TTG TGA TAA TGG CTG GAA-3'. The cDNA was amplified using the real-time PCR detection system (Bio-Rad, Hercules, CA, USA), and data analysis was performed using the CFX Maestro Analysis Software (Bio-Rad Laboratories, Inc.). 


\subsection{Serum Triglycerides, Cholesterols, Aspartate Transaminase (AST), and Alanine Transaminase (ALT)}

Concentrations of total triglycerides (TG), total cholesterol (TC), very-low-density lipoprotein (VLDL)/low-density lipoprotein (LDL) cholesterol, high-density lipoprotein (HDL) cholesterol, aspartate transaminase (AST), and alanine transaminase (ALT) in serum were determined by enzyme-linked colorimetric methods using commercial kits (BioVision Inc., Milpitas, CA, USA).

\subsection{Antioxidant Enzyme Activity in the Liver}

The liver tissues were lysed using the CelLytic MT lysis reagent (Sigma), and the antioxidant enzyme activity was measured using the superoxide dismutase (SOD), catalase (CAT), and glutathione peroxidase (GPx) assay kits (Biomax Inc., Seoul). Malondialdehyde (MDA), a lipid peroxidation marker, was measured using MDA assay kits (BioVision Inc., Milpitas, CA, USA).

\subsection{Expression Levels of OAT1, OAT3, GLUT9, and URAT1 Proteins}

The primary mouse renal tubular epithelial cells and kidney tissues were lysed using the CelLytic MT lysis reagent. Equal amounts of proteins $(100 \mu \mathrm{g} / \mathrm{lane})$ were separated by electrophoresis using 10\% Mini-PROTEAN TGX Precast Gels (Bio-Rad Laboratories, Inc.) and transferred to polyvinylidene difluoride membranes using Trans-Blot Turbo Transfer System (Bio-Rad Laboratories, Inc.). The membranes were incubated for $1 \mathrm{~h}$ in a blocking solution containing 5\% nonfat milk in Tris-buffered saline and further incubated for $12 \mathrm{~h}$ at $4{ }^{\circ} \mathrm{C}$ with the antibodies recognizing OAT1 (1:500; MyBioSource), OAT3 (1:1000; Santa Cruz), GLUT9 (1:800; Invitrogen), URAT1 (1:800; MyBioSource), and $\beta$-actin (1:1000; Cell Signaling Technology). Thereafter, the membranes were incubated with secondary antibodies (anti-rabbit immunoglobulin G (IgG) horseradish peroxidase (HRP)-linked antibody, 1:3000; Cell Signaling Technology, Inc.) for $1 \mathrm{~h}$ at room temperature. The immunoreactive protein bands were detected using EzWestLumi plus (ATTO, Tokyo, Japan) and analyzed using Ez-Capture II (ATTO) and CS Analyzer v.3.0 (ATTO).

\subsection{Statistical Analysis}

All data are presented as mean \pm standard deviation (SD). The data were statistically evaluated using Duncan's multiple range tests after one-way analysis of variance (ANOVA) using SPSS statistical procedures (SPSS PASW Statistic v.23.0, SPSS Inc., Chicago, IL, USA). When the data were subjected to prior investigations before analysis, parametric assumptions including homoscedasticity and normality of observations were satisfied. Differences were considered to be statistically significant at $p<0.05$ level.

\section{Results}

3.1. Luteolin and Loganin of $\mathrm{Ci}, \mathrm{Co}$, and FSH-CC

The HPLC analysis of the $\mathrm{Ci}, \mathrm{Co}$, and FSH-CC revealed three peaks matching those of the commercial standards luteolin (Figure 1A) and loganin (Figure 1B). The Ci contained $7.62 \mathrm{mg} / \mathrm{g}$ luteolin and $0 \mathrm{mg} / \mathrm{g}$ loganin, Co contained $0 \mathrm{mg} / \mathrm{g}$ luteolin and $4.90 \mathrm{mg} / \mathrm{g}$ loganin, and FSH-CC contained $3.95 \mathrm{mg} / \mathrm{g}$ luteolin and $2.48 \mathrm{mg} / \mathrm{g}$ loganin.

\subsection{The Combination of Ci and Co Suppressed the Xanthine Oxidase Activity and Xanthine Dehydrogenase mRNA Expression in Liver Cells More Than Their Individual Treatments}

We found that hypoxanthine treatment $(C)$ increased the activity of xanthine oxidase and mRNA expression of xanthine dehydrogenase as compared with those in the normal control (NC). However, $\mathrm{Ci}$ and $\mathrm{Co}$ treatments revealed a significant decrease in the activity of xanthine oxidase and mRNA expression of xanthine dehydrogenase as compared with those in the control group. In addition, the combination of Ci and Co (FSU-CC) suppressed xanthine oxidase activity and xanthine dehydrogenase mRNA expression more than the individual treatment with either Ci or Co alone. Moreover, FSU-CC 300 treatment resulted in 
the most significant reduction in the xanthine oxidase activity and xanthine dehydrogenase mRNA expression among all the hypoxanthine-treated HepG2 cells $(p<0.05)$ (Figure 2).

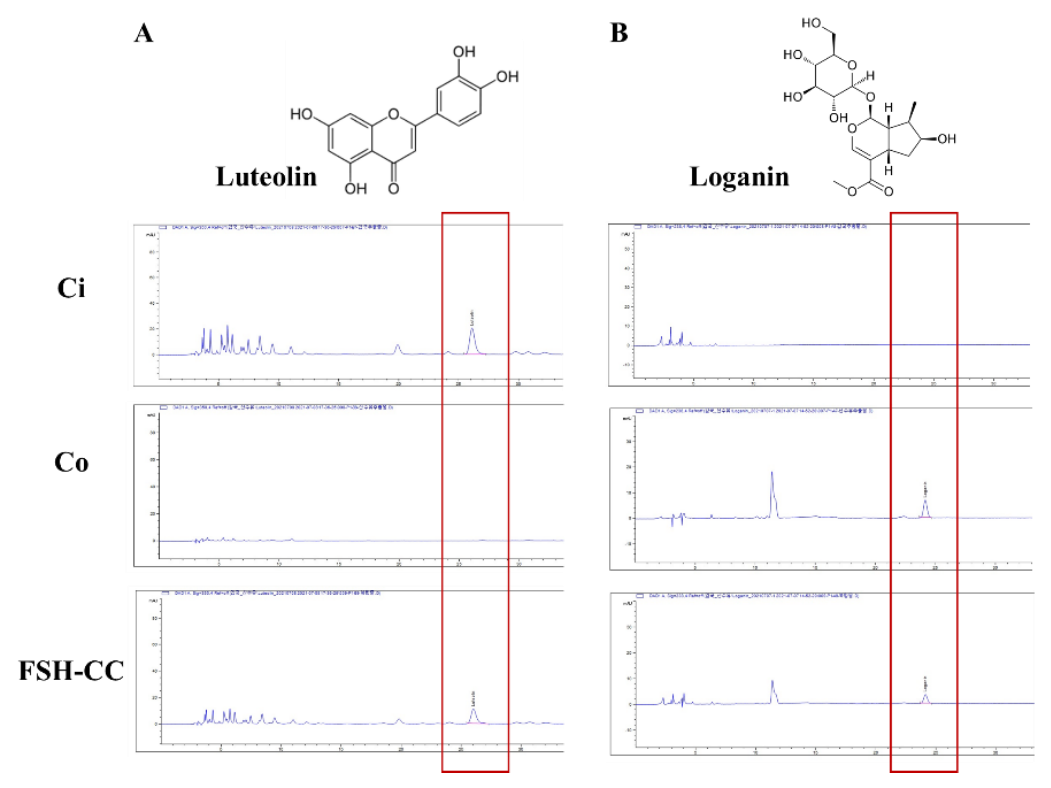

Figure 1. High-performance liquid chromatography analysis of luteolin (A) and loganin (B) levels in $\mathrm{Ci}, \mathrm{Co}$, and FSH-CC.
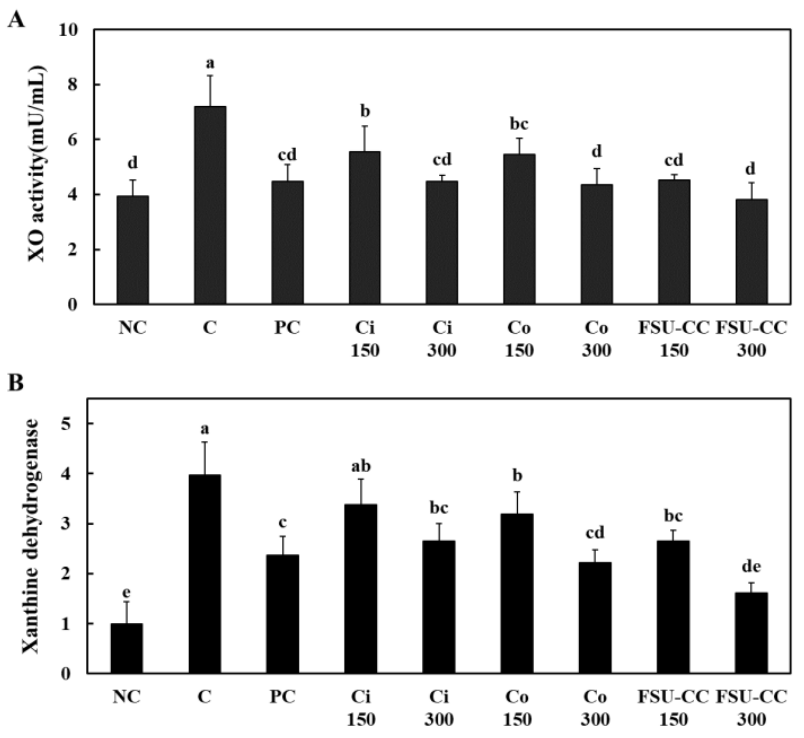

Figure 2. Xanthine oxidase activity (A) and xanthine dehydrogenase mRNA expression (B) in hypoxanthine-treated human liver cancer (HepG2) cells, with and without $\mathrm{Ci}, \mathrm{Co}$, or FSU-CC. NC: normal control, C: $4 \mathrm{mM}$ hypoxanthine, PC: $4 \mathrm{mM}$ hypoxanthine $+100 \mu \mathrm{M}$ allopurinol, $\mathrm{Ci}$ 150: $4 \mathrm{mM}$ hypoxanthine $+150 \mathrm{\mu g} / \mathrm{mL}$ Chrysanthemum indicum L., Ci 300: $4 \mathrm{mM}$ hypoxanthine $+300 \mu \mathrm{g} / \mathrm{mL}$ C. indicum L., Co 150: $4 \mathrm{mM}$ hypoxanthine $+150 \mu \mathrm{g} / \mathrm{mL}$ Cornus officinalis Siebold and Zucc., Co 300: $4 \mathrm{mM}$ hypoxanthine $+300 \mu \mathrm{g} / \mathrm{mL}$ C. officinalis Siebold and Zucc., FSU-CC 150: $4 \mathrm{mM}$ hypoxanthine $+150 \mu \mathrm{g} / \mathrm{mL}$ mixture of C. indicum L. and C. officinalis Siebold and Zucc. (1:2), FSU-CC 300: $4 \mathrm{mM}$ hypoxanthine $+300 \mu \mathrm{g} / \mathrm{mL}$ mixture of $C$. indicum L. and C. officinalis Siebold and Zucc. (1:2). Different letters indicate significant difference at $p<0.05$, as determined by Duncan's multiple range test. 
3.3. The Combination of Ci and Co Increased the Expression Levels of OAT1 and OAT3 and Suppressed the Expression Levels of GLUT9 and URAT1 in Renal Proximal Tubule Cells More Than Their Individual Treatments

We confirmed the uric acid excretion transporters, OAT1 and OAT3, as well as the uric acid reabsorption transporters, GLUT9 and URAT1, in the primary mouse renal proximal tubule cells. Hypoxanthine treatment in these cells induced a decrease in the expression levels of OAT1 and OAT3 compared with those in the normal control group, while Ci and Co treatment groups exhibited increased expression levels of OAT1 and OAT3 compared with those in the hypoxanthine control group. Moreover, the combination of $\mathrm{Ci}$ and $\mathrm{Co}$ (FSU-CC) increased the expression levels of OAT1 and OAT3 more than the individual treatment with either Ci or Co alone $(p<0.05)$ (Figure 3B,C).
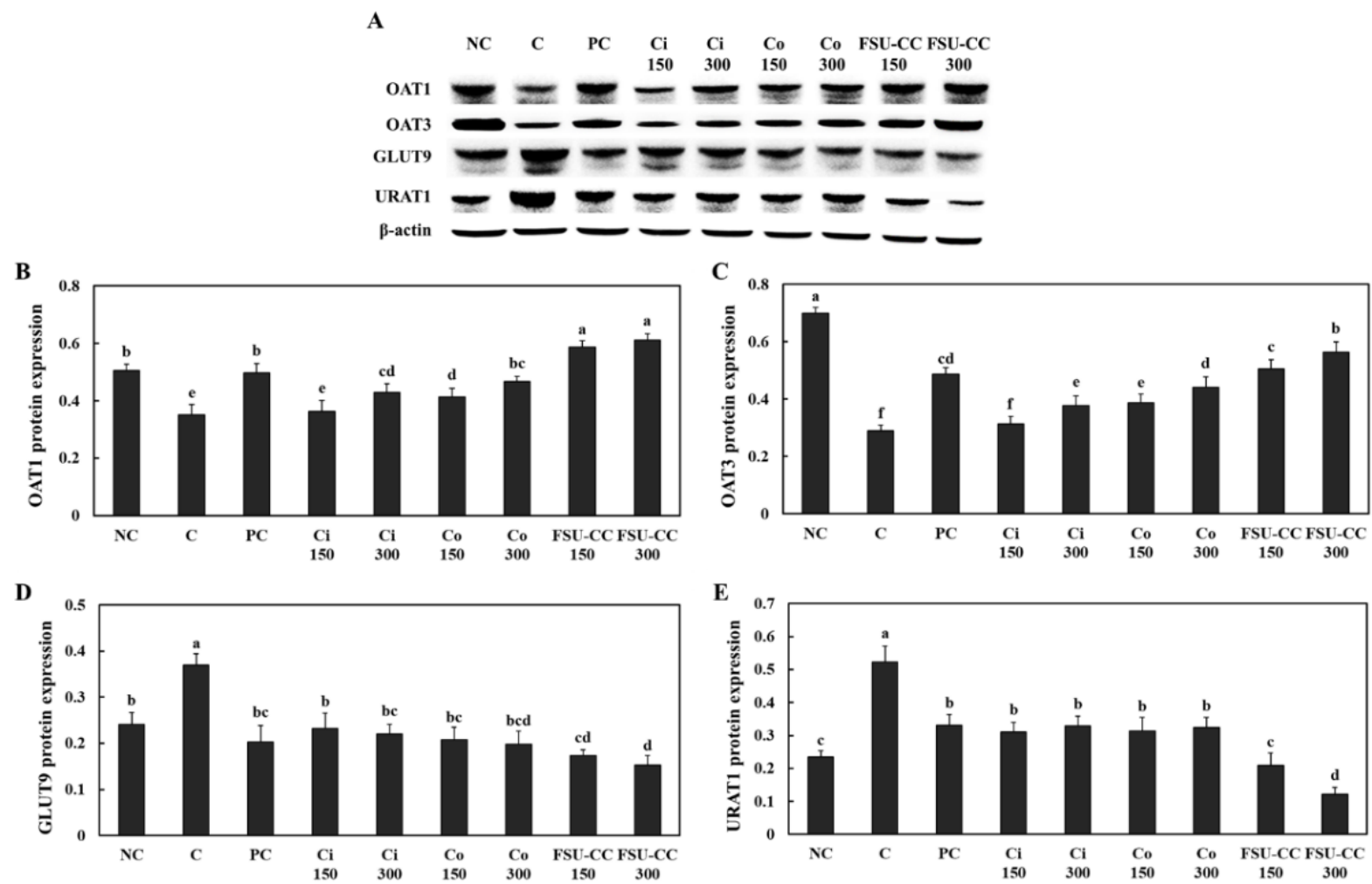

Figure 3. Expression levels of proteins by Western blotting (band images (A), relative protein expression (B-E)) in the hypoxanthine-treated primary mouse renal proximal tubule cells, with and without Ci, Co, or FSU-CC. NC: normal control, C: $4 \mathrm{mM}$ hypoxanthine, PC: $4 \mathrm{mM}$ hypoxanthine $+100 \mu \mathrm{M}$ allopurinol, Ci 150: $4 \mathrm{mM}$ hypoxanthine $+150 \mu \mathrm{g} / \mathrm{mL}$ C. indicum L., Ci 300: $4 \mathrm{mM}$ hypoxanthine $+300 \mu \mathrm{g} / \mathrm{mL}$ C. indicum L., Co 150: $4 \mathrm{mM}$ hypoxanthine $+150 \mu \mathrm{g} / \mathrm{mL}$ C. officinalis Siebold and Zucc., Co 300: $4 \mathrm{mM}$ hypoxanthine $+300 \mu \mathrm{g} / \mathrm{mL}$ C. officinalis Siebold and Zucc., FSU-CC 150: 4 mM hypoxanthine $+150 \mu \mathrm{g} / \mathrm{mL}$ mixture of C. indicum L. and C. officinalis Siebold and Zucc. (1:2), FSU-CC 300: 4 mM hypoxanthine $+300 \mu \mathrm{g} / \mathrm{mL}$ mixture of C. indicum L. and C. officinalis Siebold and Zucc. (1:2). Different letters indicate significant difference at $p<0.05$, as determined by Duncan's multiple range test.

Compared to the normal control group, hypoxanthine treatment induced an increase in the expression levels of GLUT9 and URAT1 in the primary mouse renal proximal tubule cells, while $\mathrm{Ci}$ and $\mathrm{Co}$ treatment groups exhibited significantly decreased expression levels of GLUT9 and URAT1 compared with those in the hypoxanthine treatment control group. Moreover, the combination of $\mathrm{Ci}$ and $\mathrm{Co}$ (FSU-CC) decreased expression levels of GLUT9 and URAT1 more than the individual treatment with either Ci or Co alone $(p<0.05)$ (Figure 3D,E). 


\subsection{The Combination of Ci and Co Increased the Excretion of Creatinine and Uric Acid in Hyperuricemia-Induced Mice More Than Their Individual Treatments}

We investigated the effects of $\mathrm{Ci}$ and $\mathrm{Co}$ supplementation on hyperuricemia-induced mice and found that $\mathrm{Ci}$ and $\mathrm{Co}$ supplementation did not affect the change in the levels of serum ALT, AST, triglycerides, total cholesterol, HDL cholesterol, and LDL cholesterol in hyperuricemia-induced mice (Table 1). We measured the levels of creatinine and uric acid in the serum and urine in hyperuricemia-induced mice to confirm whether $\mathrm{Ci}$ and Co supplementation affects the excretion of creatinine and uric acid in them. Compared to the normal control, hyperuricemia-induced mice showed a significant increase in the levels of creatinine and uric acid in the serum and a significant decrease in the levels of creatinine and uric acid in the urine. Ci 300 and Co 300 supplementation groups exhibited significantly decreased levels of creatinine and uric acid in the serum and increased levels of creatinine and uric acid in the urine as compared with those in the control group. FSU-CC 300 decreased the levels of creatinine and uric acid in the serum and increased the levels of creatinine and uric acid in the urine more than the individual supplementation of either $\mathrm{Ci}$ 300 or Co 300 alone $(p<0.05)$ (Figure 4$)$.

Table 1. Changes in the levels of serum alanine transaminase (ALT), aspartate transaminase (AST), triglycerides, total cholesterol, high-density lipoprotein (HDL) cholesterol, and low-density lipoprotein (LDL) cholesterol in the hyperuricemia-induced mice supplemented with and without Ci, Co, or FSU-CC.

\begin{tabular}{|c|c|c|c|c|c|c|}
\hline & $\underset{(\mathrm{mU} / \mathrm{mL})}{\mathrm{AST}}$ & $\underset{(\mathrm{mU} / \mathrm{mL})}{\text { ALT }}$ & $\begin{array}{c}\text { Triglycerides } \\
(\mu \mathrm{g} / \mathrm{mL})\end{array}$ & $\begin{array}{c}\text { Total } \\
\text { cholesterol } \\
(\mu \mathrm{g} / \mathrm{mL})\end{array}$ & $\begin{array}{c}\text { HDL } \\
(\mu \mathrm{g} / \mathrm{mL})\end{array}$ & $\begin{array}{c}\mathrm{LDL} \\
(\mu \mathrm{g} / \mathrm{mL})\end{array}$ \\
\hline $\mathrm{NC}$ & $22.79 \pm 3.34^{\mathrm{ns}}$ & $3.37 \pm 0.41^{\mathrm{ns}}$ & $2.60 \pm 0.39^{\text {ns }}$ & $7.58 \pm 0.72^{\text {ns }}$ & $1.72 \pm 0.24^{\mathrm{ns}}$ & $1.63 \pm 0.89^{\text {ns }}$ \\
\hline $\mathrm{C}$ & $23.02 \pm 2.26$ & $2.91 \pm 0.64$ & $2.26 \pm 0.14$ & $8.06 \pm 0.81$ & $1.89 \pm 0.29$ & $1.74 \pm 0.84$ \\
\hline PC & $21.83 \pm 2.49$ & $2.91 \pm 0.35$ & $2.62 \pm 0.26$ & $7.75 \pm 0.83$ & $1.70 \pm 0.34$ & $1.30 \pm 0.91$ \\
\hline Ci 300 & $23.66 \pm 2.13$ & $3.06 \pm 0.77$ & $2.63 \pm 0.37$ & $7.56 \pm 0.97$ & $1.74 \pm 0.32$ & $1.61 \pm 0.75$ \\
\hline Co 300 & $23.39 \pm 2.18$ & $3.13 \pm 0.48$ & $2.44 \pm 0.33$ & $8.33 \pm 0.56$ & $1.75 \pm 0.19$ & $1.55 \pm 092$ \\
\hline FSU-CC 150 & $22.77 \pm 1.29$ & $2.79 \pm 0.32$ & $2.47 \pm 0.42$ & $7.60 \pm 0.76$ & $1.80 \pm 0.33$ & $1.30 \pm 1.55$ \\
\hline FSU-CC 300 & $24.08 \pm 6.82$ & $3.25 \pm 0.58$ & $2.43 \pm 0.14$ & $7.72 \pm 1.46$ & $1.57 \pm 0.22$ & $1.38 \pm 1.32$ \\
\hline FSU-CC 600 & $22.85 \pm 1.36$ & $3.24 \pm 0.78$ & $2.61 \pm 0.19$ & $7.11 \pm 0.56$ & $1.64 \pm 0.27$ & $1.24 \pm 0.79$ \\
\hline
\end{tabular}

ns not significant. NC: normal control, C: hyperuricemia-induced mice, PC: hyperuricemia-induced mice with oral supplementation of allopurinol $10 \mathrm{mg} / \mathrm{kg}$ b.w., Ci 300: hyperuricemia-induced mice with oral supplementation of C. indicum L. $300 \mathrm{mg} / \mathrm{kg}$ b.w., Co 300: hyperuricemia-induced mice with oral supplementation of C. officinalis Siebold and Zucc. $300 \mathrm{mg} / \mathrm{kg}$ b.w., FSU-CC 150: hyperuricemia-induced mice with oral supplementation of mixture of C. indicum L. and C. officinalis Siebold and Zucc. (1:2) $150 \mathrm{mg} / \mathrm{kg}$ b.w., FSU-CC 300: hyperuricemiainduced mice with oral supplementation of mixture of C. indicum L. and C. officinalis Siebold and Zucc. (1:2) $300 \mathrm{mg} / \mathrm{kg}$ b.w., FSU-CC 600: hyperuricemia-induced mice with oral supplementation of mixture of C. indicum L. and C. officinalis Siebold and Zucc. (1:2) $600 \mathrm{mg} / \mathrm{kg}$ b.w. Different letters indicate significant difference at $p<0.05$, as determined by Duncan's multiple range test.

\subsection{The Combination of Ci and Co Increased the Xanthine Oxidase Activity and Xanthine} Dehydrogenase mRNA Expression and Inhibited the Oxidative Stress in Hyperuricemia-Induced Mice More Than Their Individual Treatments

We measured the xanthine oxidase activity, xanthine dehydrogenase mRNA expression, and oxidative stress in the liver of hyperuricemia-induced mice. The xanthine oxidase activity and xanthine dehydrogenase mRNA expression in the liver were significantly increased in the hyperuricemia-induced mice group compared with those in the normal control group. However, Ci 300 and Co 300 supplementation suppressed the xanthine oxidase activity and xanthine dehydrogenase mRNA expression in the liver of hyperuricemiainduced mice. FSU-CC 300 supplementation significantly decreased the xanthine oxidase activity and xanthine dehydrogenase mRNA expression in the liver of hyperuricemiainduced mice more than the individual supplementation of either Ci 300 or Co 300 alone $(p<0.05)$ (Figure 5A,B).

We found that hyperuricemia-induced mice exhibited an increase in the MDA levels and a decrease in the activities of antioxidant enzymes, including SOD, CAT, and GPx, compared with those in the normal control group. Ci 300, Co 300, and FSU-CC supplementation induced a decrease in the MDA levels and an increase in the antioxidant enzyme activities compared with those in the control group $(p<0.05)$ (Figure $5 \mathrm{C}-\mathrm{F}$ ). 

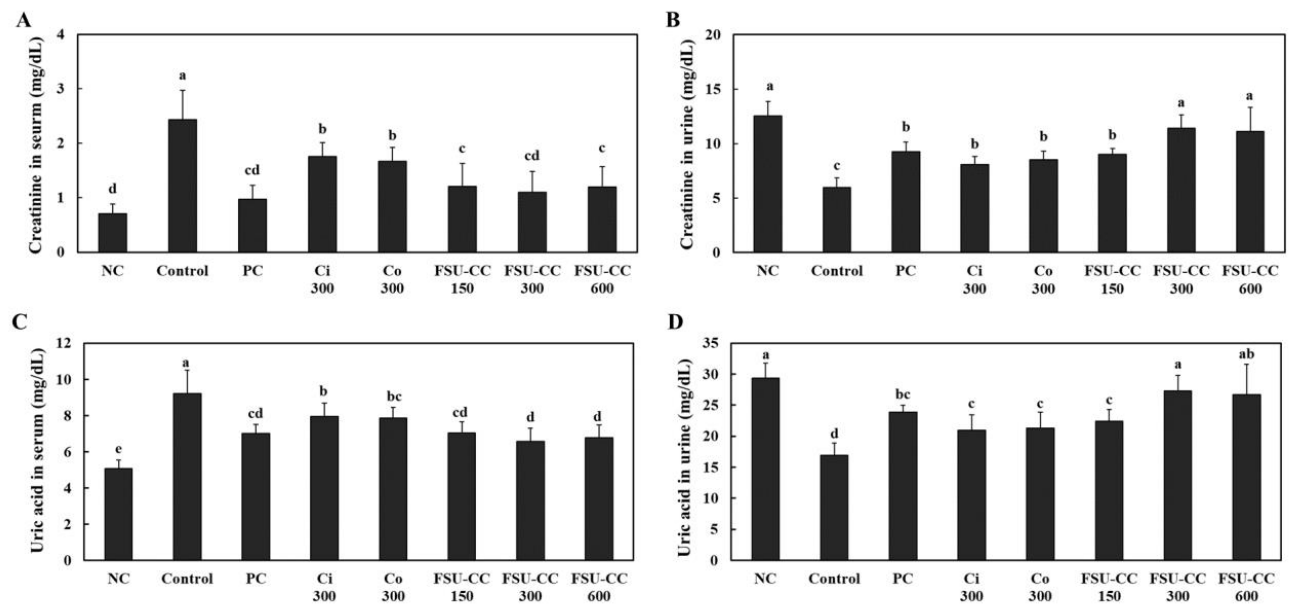

Figure 4. Levels of creatinine in serum (A) and urine (B) and uric acid in serum (C) and urine (D) in the hyperuricemiainduced mice supplemented with and without Ci, Co, or FSU-CC. NC: normal control, C: hyperuricemia-induced mice, PC: hyperuricemia-induced mice with oral supplementation of allopurinol $10 \mathrm{mg} / \mathrm{kg}$ b.w., Ci 300: hyperuricemia-induced mice with oral supplementation of C. indicum L. $300 \mathrm{mg} / \mathrm{kg}$ b.w., Co 300: hyperuricemia-induced mice with oral supplementation of C. officinalis Siebold and Zucc. $300 \mathrm{mg} / \mathrm{kg}$ b.w., FSU-CC 150: hyperuricemia-induced mice with oral supplementation of mixture of C. indicum L. and C. officinalis Siebold and Zucc. (1:2) $150 \mathrm{mg} / \mathrm{kg}$ b.w., FSU-CC 300: hyperuricemia-induced mice with oral supplementation of mixture of C. indicum L. and C. officinalis Siebold and Zucc. (1:2) $300 \mathrm{mg} / \mathrm{kg}$ b.w., FSU-CC 600: hyperuricemia-induced mice with oral supplementation of mixture of C. indicum L. and C. officinalis Siebold and Zucc. (1:2) $600 \mathrm{mg} / \mathrm{kg}$ b.w. Different letters indicate significant difference at $p<0.05$, as determined by Duncan's multiple range test.
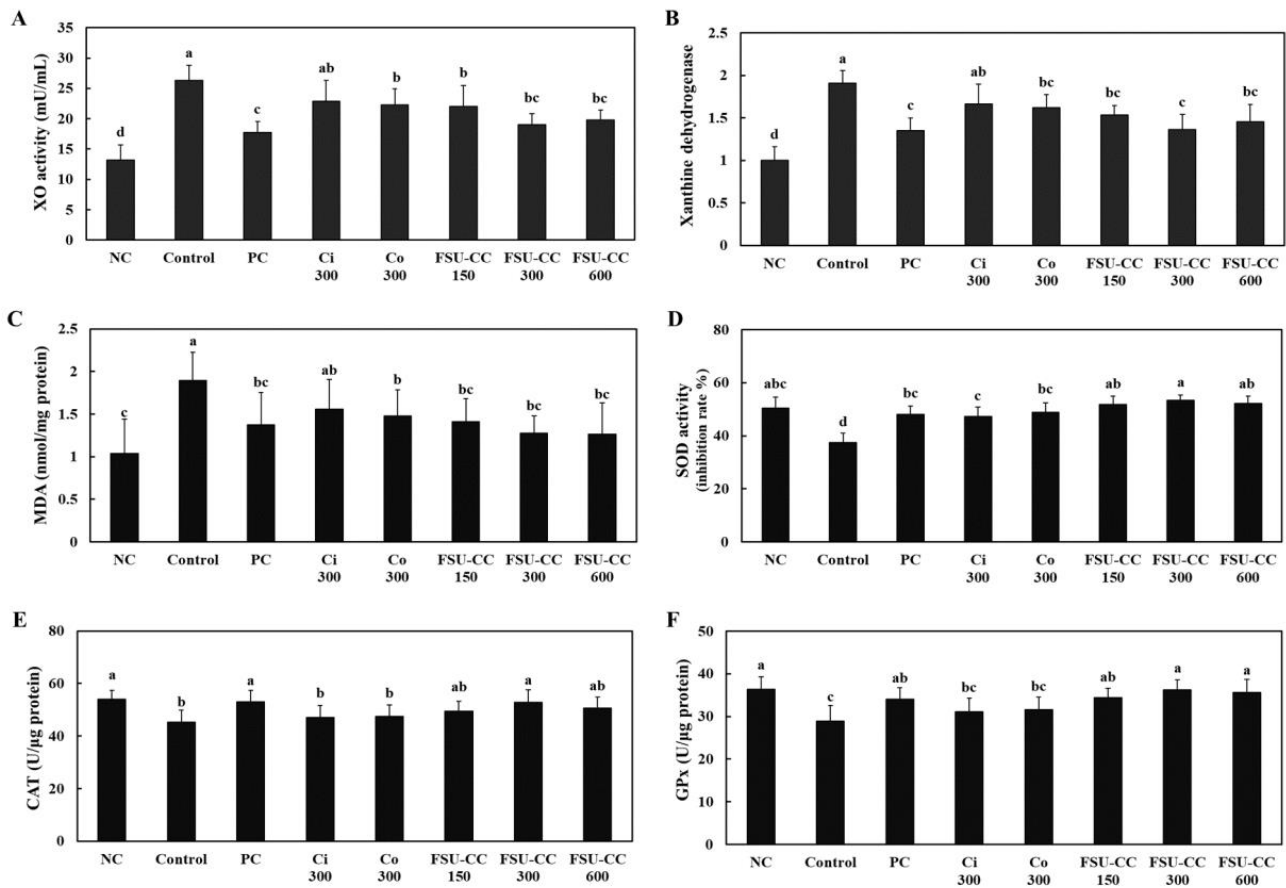

Figure 5. Xanthine oxidase activity (A); xanthine dehydrogenase mRNA expression (B); malondialdehyde (MDA) levels (C); and activities of superoxide dismutase (SOD) (D), catalase (CAT) (E), and glutathione peroxidase (GPx) (F) in the liver from hyperuricemia-induced mice supplemented with and without Ci, Co, or FSU-CC. NC: normal control, C: hyperuricemia-induced mice, PC: hyperuricemia-induced mice with oral supplementation of allopurinol $10 \mathrm{mg} / \mathrm{kg}$ b.w., Ci 300: hyperuricemia-induced mice with oral supplementation of C. indicum L. $300 \mathrm{mg} / \mathrm{kg}$ b.w., Co 300: hyperuricemia-induced mice with oral supplementation of C. officinalis Siebold and Zucc. $300 \mathrm{mg} / \mathrm{kg}$ b.w., FSU-CC 150: hyperuricemia-induced mice with oral supplementation of mixture of C. indicum L. and C. officinalis Siebold and Zucc. (1:2) $150 \mathrm{mg} / \mathrm{kg}$ b.w., FSU-CC 300: hyperuricemia-induced mice with oral supplementation of mixture of C. indicum L. and C. officinalis Siebold and Zucc. (1:2) $300 \mathrm{mg} / \mathrm{kg}$ b.w., FSUCC 600: hyperuricemia-induced mice with oral supplementation of mixture of C. indicum L. and C. officinalis Siebold and Zucc. (1:2) $600 \mathrm{mg} / \mathrm{kg}$ b.w. Different letters indicate significant difference at $p<0.05$, as determined by Duncan's multiple range test. 
3.6. The Combination of Ci and Co Increased the Expression Levels of OAT1 and OAT3 and Suppressed the Expression Levels of GLUT9 and URAT1 in Hyperuricemia-Induced Mice More Than Their Individual Treatments

Hyperuricemia-induced mice showed a decrease in the expression levels of OAT1 and OAT3 in the kidney compared with those in the normal control group. Ci 300 and Co 300 supplementation increased the expression levels of OAT1 and OAT3 in the kidney of hyperuricemia-induced mice compared with those in the control group. In addition, FSU-CC 300 supplementation significantly increased the expression levels of OAT1 and OAT3 in the kidney more than the individual supplementation of either Ci 300 or Co 300 alone $(p<0.05)$ (Figure 6B,C).

Hyperuricemia-induced mice exhibited an increase in the expression levels of GLUT9 and URAT1 in the kidney as compared to the normal control. Ci 300 and Co 300 supplementation significantly decreased the expression levels of GLUT9 and URAT1 in the kidney compared with those in the control group. Moreover, FSU-CC 300 decreased the expression levels of GLUT9 and URAT1 in the kidney of hyperuricemia-induced mice more than the individual supplementation of either Ci 300 or Co 300 alone $(p<0.05)$ (Figure $6 \mathrm{D}, \mathrm{E}$ ).

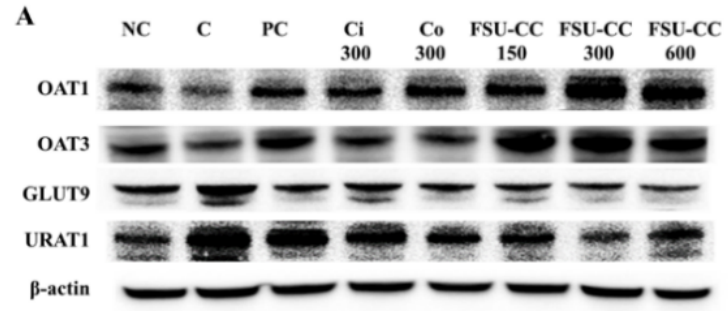

B
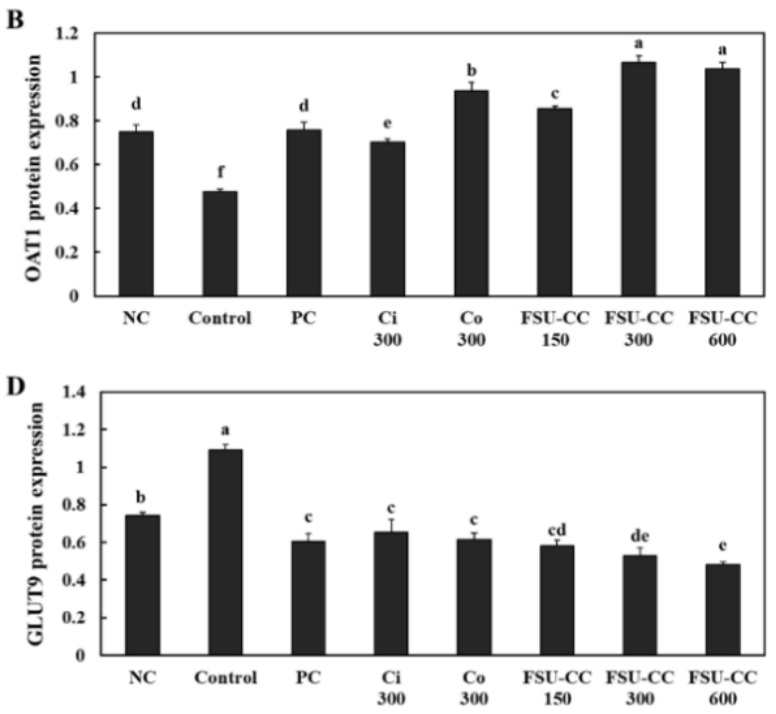
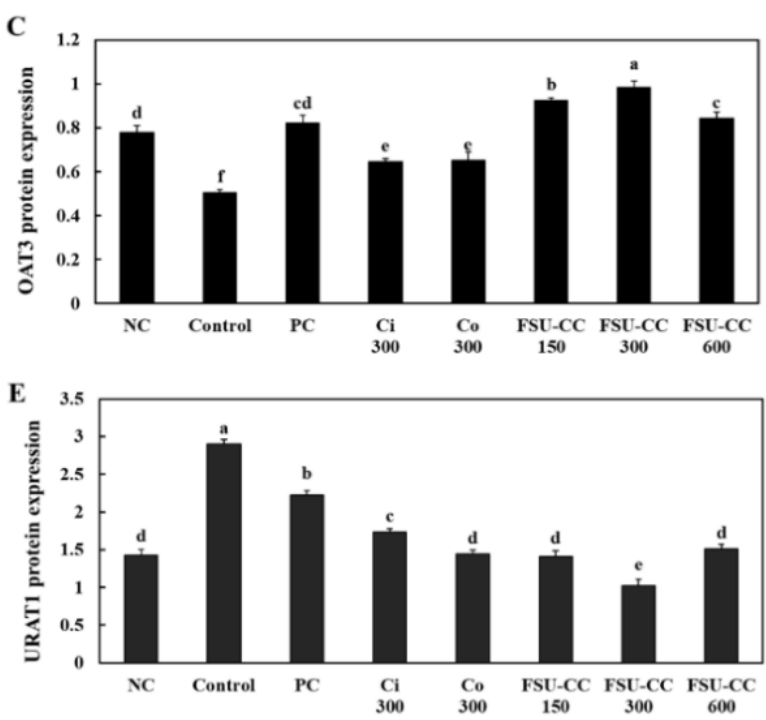

Figure 6. Expression levels of proteins by Western blotting (band images (A), relative protein expression (B-E)) in the kidney of hyperuricemia-induced mice supplemented with and without $\mathrm{Ci}, \mathrm{Co}$, or FSU-CC. NC: normal control, C: hyperuricemia-induced mice, PC: hyperuricemia-induced mice with oral supplementation of allopurinol $10 \mathrm{mg} / \mathrm{kg}$ b.w., Ci 300: hyperuricemia-induced mice with oral supplementation of C. indicum L. 300 mg $/ \mathrm{kg}$ b.w., Co 300: hyperuricemiainduced mice with oral supplementation of C. officinalis Siebold and Zucc. 300 mg/kg b.w., FSU-CC 150: hyperuricemiainduced mice with oral supplementation of mixture of C. indicum $\mathrm{L}$. and C. officinalis Siebold and Zucc. (1:2) $150 \mathrm{mg} / \mathrm{kg}$ b.w., FSU-CC 300: hyperuricemia-induced mice with oral supplementation of mixture of $C$. indicum L. and C. officinalis Siebold and Zucc. (1:2) $300 \mathrm{mg} / \mathrm{kg}$ b.w., FSU-CC 600: hyperuricemia-induced mice with oral supplementation of mixture of C. indicum L. and C. officinalis Siebold and Zucc. (1:2) $600 \mathrm{mg} / \mathrm{kg}$ b.w. Different letters indicate significant difference at $p<0.05$, as determined by Duncan's multiple range test. 


\section{Discussion}

Recently, the prevalence of hyperuricemia-induced gout has been increasing, and the treatment for gout includes the use of nonsteroidal anti-inflammatory drugs to relieve the symptoms of the illness and the use of allopurinol and xanthine oxidase inhibitors to reduce the production of uric acid [15]. However, these drugs have side effects, including gastrointestinal toxicity and bleeding, renal toxicity, and hypersensitivity reactions [16] Therefore, alternative therapies have been explored in an attempt to treat and prevent hyperuricemia $[17,18]$. We compared the effects of $\mathrm{Ci}, \mathrm{Co}$, and a combination of $\mathrm{Ci}$ and $\mathrm{Co}$ (FSU-CC) on hyperuricemia-induced HepG2 cells, primary mouse renal proximal tubule cells, and potassium oxonate induced hyperuricemic mice. The flowers of $C$. indicum $\mathrm{L}$. and fruits of $C$. officinalis Siebold and Zucc. are widely known for their health benefits as traditional tea and are accepted for use as food in Korea $[19,20]$. The present study aimed to compare the effects of $\mathrm{Ci}, \mathrm{Co}$, and a combination and to develop agents for the prevention of hyperuricemia.

Xanthine oxidase, converted from xanthine dehydrogenase, acts as a key enzyme for the oxidation of hypoxanthine and xanthine during the production of uric acid in the liver. It is well known that the mitochondrial ROS are produced during the xanthine oxidase mediated production of uric acid $[7,8]$. We found an increase in the xanthine oxidase activity and xanthine dehydrogenase mRNA expression in hypoxanthine-treated HepG2 cells and the liver of potassium oxonate induced hyperuricemic mice as compared to that in the normal cells and liver of healthy mice. In addition, the potassium oxonate induced hyperuricemic mice exhibited oxidative stress in the liver due to a decrease in antioxidant enzyme activities and increase in MDA levels. However, treatment with $\mathrm{Ci}$, $\mathrm{Co}$, and FSU-CC suppressed the xanthine oxidase activity, xanthine dehydrogenase mRNA expression, and oxidative stress in hypoxanthine-treated HepG2 cells and the liver of potassium oxonate induced hyperuricemic mice. We found that the combination of $\mathrm{Ci}$ and Co inhibited the activity of xanthine oxidase more than either of the two given separately.

The study of Nishida [21] has demonstrated the significant positive correlations between the excretion of creatinine and uric acid in urine. Thus, we measured the levels of creatinine and uric acid in the serum and urine to observe the excretion process of creatinine and uric acid. Supplementation of $\mathrm{Ci}, \mathrm{Co}$, and FSU-CC increased the excretion of creatinine and uric acid through urine, which was suppressed by potassium oxonate injection in mice. Moreover, the excretion of creatinine and uric acid in the combination of $\mathrm{Ci}$ and $\mathrm{Co}$ was higher than that of individual supplementation and was similar to that of the normal group. These results indicate that the combination of $\mathrm{Ci}$ and $\mathrm{Co}$ helps to treat hyperuricemia more than individual dietary supplements.

In order to elucidate the mechanisms of $\mathrm{Ci}, \mathrm{Co}$, and FSU-CC that mediate the excretion of uric acid in hyperuricemia, we observed the expression of the transporters involved in uric acid excretion in hypoxanthine-treated primary mouse renal proximal tubule cells and the kidney from potassium oxonate induced hyperuricemic mice. Previous studies have identified GLUT9 and URAT1, involved in uric acid reabsorption, and OAT1 and OAT3, involved in uric acid excretion, as potential therapeutic targets for hyperuricemia $[10,22,23]$. We have shown in the present study that $\mathrm{Ci}, \mathrm{Co}$, and FSU-CC significantly increased the expression levels of OAT1 and OAT3 while decreasing the expression levels of GLUT9 and URAT1 in hypoxanthine-treated primary mouse renal proximal tubule cells and the kidney from potassium oxonate induced hyperuricemic mice. Moreover, the combination of $\mathrm{Ci}$ and Co increased the expression levels of OAT1 and OAT3 and suppressed the expression levels of GLUT9 and URAT1 more than the individual treatments. Therefore, we hypothesize that FSU-CC aids in maintaining the function of these uric acid transporters to prevent hyperuricemia more than the individual treatment with either $\mathrm{Ci}$ or $\mathrm{Co}$ alone.

We showed that $\mathrm{Ci}$ contained luteolin, a common flavonoid, and Co contained loganin, an iridoid glycoside. Matsuda et al. isolated new flavanone glycosides and a phenylbutanoid glycoside from the flowers of C. indicum L. and found inhibitory activity for rat lens aldose reductase [24]. Dong et al. showed the various pharmacological activities 
of the C. officinalis Siebold and Zucc. extract and found chemical compounds, including terpenoids, flavonoids, and tannin, identified from C. officinalis Siebold and Zucc. [20]. Several studies have demonstrated that treatment with phenolic compounds suppresses the development of hyperuricemia in vitro, in vivo, and in human clinical trial studies [25-27]. According to these reports and our present results, we can assume that phenolic compounds from $\mathrm{Ci}$ and $\mathrm{Co}$ can have hypouricemic effects on hyperuricemia-induced HepG2 cells, renal cells, and mice. However, further human clinical trials are needed to fully understand the effects of dietary supplementation with both $\mathrm{Ci}$ and $\mathrm{Co}$ on hyperuricemia.

\section{Conclusions}

We compared the effects of extracts from $\mathrm{Ci}, \mathrm{Co}$, and FSU-CC on hyperuricemia using hypoxanthine-treated HepG2 cells, primary mouse renal proximal tubule cells, and potassium oxonate induced hyperuricemic mice. We found that the FSU-CC treatment inhibited the production and excretion of uric acid more than the individual treatment with either $\mathrm{Ci}$ or $\mathrm{Co}$ alone in both in vitro and in vivo models. We confirmed that treatment with FSU-CC directly inhibited the production of uric acid in hepatocytes and increased the expression of uric acid transporters in renal cells, which are involved in the excretion process (Figure 7). This study provides scientific evidence and describes the underlying mechanisms responsible for the anti-hyperuricemic effects of $\mathrm{Ci}$ and Co. Therefore, our data suggest that a combination of $\mathrm{Ci}$ and $\mathrm{Co}$ may potentially be used for the development of effective natural anti-hyperuricemic agents.

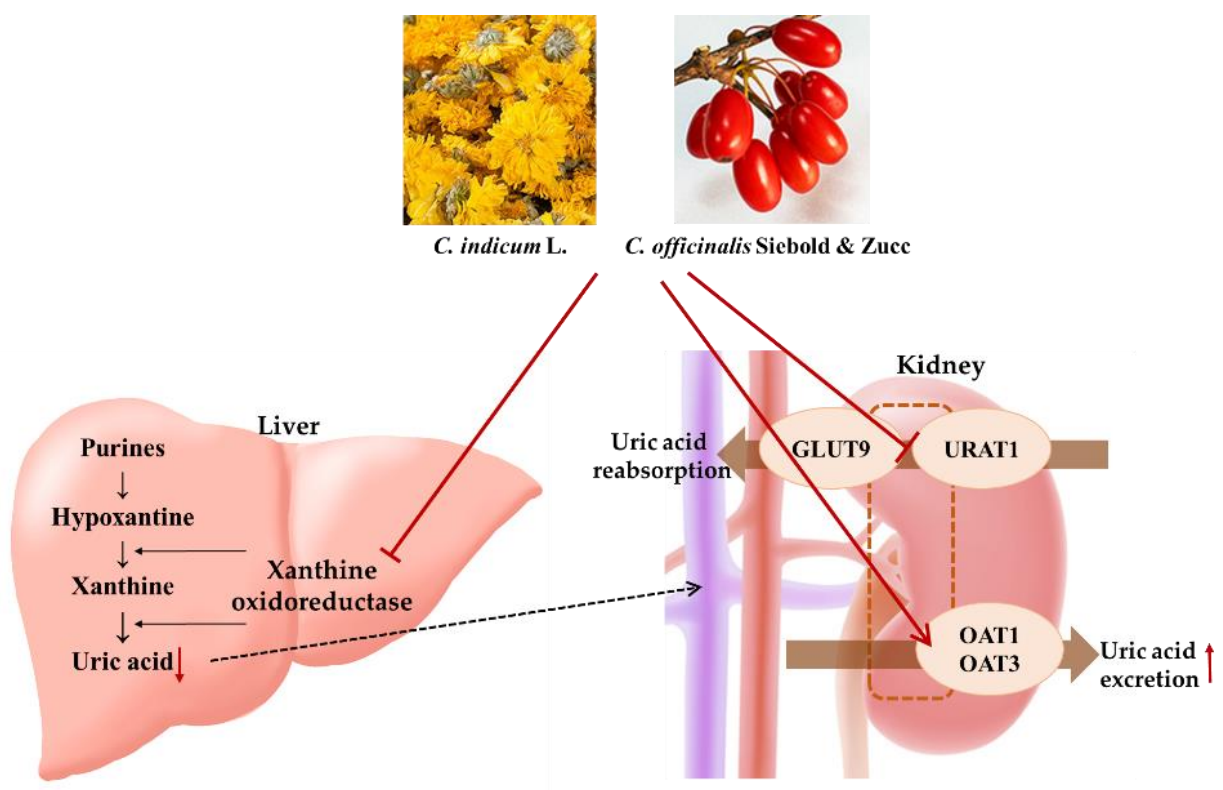

Figure 7. Schematic representation of the effect of Ci, Co, or FSU-CC on hyperuricemia. Ci, Co, or FSU-CC inhibited the production of uric acid in the liver and excretion of uric acid in the renal cells.

Author Contributions: O.-K.K. and J.L. designed the experiments; O.-K.K., J.-M.Y., M.L. and D.K. performed the experiments; J.-M.Y. and M.L. analyzed the data; O.-K.K. and J.L. wrote the manuscript. All authors have read and agreed to the published version of the manuscript.

Funding: This research was supported by 2020 Collaborative R\&BD Program of The Food Industry Promotional Agency of Korea.

Institutional Review Board Statement: The Institutional Animal Care and Use Committee of Kyung Hee University ap-proved the protocol (KHGASP-20-410) for the use of animals in this study. The animals were cared for in accordance with the "Guidelines for Animal Experiments" established by the university.

Informed Consent Statement: Not applicable. 


\section{Data Availability Statement: Not applicable.}

Conflicts of Interest: The authors declare no conflict of interest.

\section{References}

1. Pedley, A.M.; Benkovic, S.J. A New View into the Regulation of Purine Metabolism: The Purinosome. Trends Biochem. Sci. 2017, 42, 141-154. [CrossRef] [PubMed]

2. Borghi, C.; Agabiti-Rosei, E.; Johnson, R.J.; Kielstein, J.T.; Lurbe, E.; Mancia, G.; Redon, J.; Stack, A.G.; Tsioufis, K.P. Hyperuricaemia and gout in cardiovascular, metabolic and kidney disease. Eur. J. Intern. Med. 2020, 80, 1-11. [CrossRef] [PubMed]

3. Martinon, F.; Pétrilli, V.; Mayor, A.; Tardivel, A.; Tschopp, J. Gout-associated uric acid crystals activate the NALP3 inflammasome. Nature 2006, 440, 237-241. [CrossRef]

4. Dehlin, M.; Jacobsson, L.; Roddy, E. Global epidemiology of gout: Prevalence, incidence, treatment patterns and risk factors. Nat. Rev. Rheumatol. 2020, 16, 380-390. [CrossRef]

5. Battelli, M.G.; Bortolotti, M.; Polito, L.; Bolognesi, A. The role of xanthine oxidoreductase and uric acid in metabolic syndrome. Biochim. Biophys. Acta. Mol. Basis Dis. 2018, 1864, 2557-2565. [CrossRef]

6. Furuhashi, M.; Matsumoto, M.; Tanaka, M.; Moniwa, N.; Murase, T.; Nakamura, T.; Ohnishi, H.; Saitoh, S.; Shimamoto, K.; Miura, T. Plasma Xanthine Oxidoreductase Activity as a Novel Biomarker of Metabolic Disorders in a General Population. Circ. J. 2018, 82, 1892-1899. [CrossRef]

7. Nishino, T.; Okamoto, K.; Eger, B.T.; Pai, E.F.; Nishino, T. Mammalian xanthine oxidoreductase-mechanism of transition from xanthine dehydrogenase to xanthine oxidase. FEBS J. 2008, 275, 3278-3289. [CrossRef] [PubMed]

8. Liu, N.; Xu, H.; Sun, Q.; Yu, X.; Chen, W.; Wei, H.; Jiang, J.; Xu, Y.; Lu, W. The Role of Oxidative Stress in Hyperuricemia and Xanthine Oxidoreductase (XOR) Inhibitors. Oxid. Med. Cell Longev. 2021, 26, 1470380.

9. Kang, D.H.; Nakagawa, T. Uric acid and chronic renal disease: Possible implication of hyperuricemia on progression of renal disease. Semin. Nephrol. 2005, 25, 43-49. [CrossRef]

10. Xu, L.; Shi, Y.; Zhuang, S.; Liu, N. Recent advances on uric acid transporters. Oncotarget 2017, 8, 100852-100862. [CrossRef]

11. Lipkowitz, M.S. Regulation of uric acid excretion by the kidney. Curr. Rheumatol. Rep. 2012, 14, 179-188. [CrossRef] [PubMed]

12. Shao, Y.; Sun, Y.; Li, D.; Chen, Y. Chrysanthemum indicum L.: A Comprehensive Review of its Botany, Phytochemistry and Pharmacology. Am. J. Chin. Med. 2020, 48, 871-897. [CrossRef]

13. Yu, H.; Yao, S.; Zhou, C.; Fu, F.; Luo, H.; Du, W.; Jin, H.; Tong, P.; Chen, D.; Wu, C.; et al. Morroniside attenuates apoptosis and pyroptosis of chondrocytes and ameliorates osteoarthritic development by inhibiting NF- $\mathrm{KB}$ signaling. J. Ethnopharmacol. 2021, 266, 113447. [CrossRef]

14. Gao, X.; Liu, Y.; An, Z.; Ni, J. Active Components and Pharmacological Effects of Cornus officinalis: Literature Review. Front. Pharmacol. 2021, 12, 633447. [CrossRef]

15. Lu, X.; Zeng, R.; Lin, J.; Hu, J.; Rong, Z.; Xu, W.; Liu, Z.; Zeng, W. Pharmacological basis for use of madecassoside in gouty arthritis: Anti-inflammatory, anti-hyperuricemic, and NLRP3 inhibition. Immunopharmacol. Immunotoxicol. 2019, 41, 277-284. [CrossRef] [PubMed]

16. Grassi, D.; Pontremoli, R.; Bocale, R.; Ferri, C.; Desideri, G. Therapeutic approaches to chronic hyperuricemia and gout. High Blood Press. Cardiovasc. Prev. 2014, 21, 243-250. [CrossRef]

17. Zhang, K.H.; Wang, M.Q.; Wei, L.L.; Feng, C.J.; Zhang, Y.S.; Teng, J.B. Investigation of the Effects and Mechanisms of Dendrobium loddigesii Rolfe Extract on the Treatment of Gout. Evid. Based Complement. Alternat. Med. 2020, 30, 4367347. [CrossRef] [PubMed]

18. Jang, M.G.; Song, H.; Kim, J.H.; Oh, J.M.; Park, J.Y.; Ko, H.C.; Hur, S.P.; Kim, S.J. Prevention of Hyperuricemia by Clerodendrum trichotomum Leaf Extract in Potassium Oxonate-Induced Mice. Dev. Reprod. 2020, 24, 89-100. [CrossRef]

19. Jeong, S.C.; Kim, S.M.; Jeong, Y.T.; Song, C.H. Hepatoprotective effect of water extract from Chrysanthemum indicum L. flower. Chin. Med. 2013, 8, 7. [CrossRef] [PubMed]

20. Dong, Y.; Feng, Z.L.; Chen, H.B.; Wang, F.S.; Lu, J.H. Corni Fructus: A review of chemical constituents and pharmacological activities. Chin. Med. 2018, 13, 34. [CrossRef] [PubMed]

21. Nishida, Y. Relation between creatinine and uric acid excretion. Ann. Rheum. Dis. 1992, 51, 101-102. [CrossRef] [PubMed]

22. Novikov, A.; Fu, Y.; Huang, W.; Freeman, B.; Patel, R.; van Ginkel, C.; Koepsell, H.; Busslinger, M.; Onishi, A.; Nespoux, J.; et al. SGLT2 inhibition and renal urate excretion: Role of luminal glucose, GLUT9, and URAT1. Am. J. Physiol. Ren. Physiol. 2019, 316, 173-185. [CrossRef] [PubMed]

23. Wu, W.; Bush, K.T.; Nigam, S.K. Key Role for the Organic Anion Transporters, OAT1 and OAT3, in the in vivo Handling of Uremic Toxins and Solutes. Sci. Rep. 2017, 7, 4939. [CrossRef]

24. Matsuda, H.; Morikawa, T.; Toguchida, I.; Harima, S.; Yoshikawa, M. Medicinal flowers. VI. Absolute stereostructures of two new flavanone glycosides and a phenylbutanoid glycoside from the flowers of Chrysanthemum indicum L.: Their inhibitory activities for rat lens aldose reductase. Chem. Pharm. Bull. 2002, 50, 972-975. [CrossRef] [PubMed]

25. Mehmood, A.; Zhao, L.; Wang, C.; Nadeem, M.; Raza, A.; Ali, N.; Shah, A.A. Management of hyperuricemia through dietary polyphenols as a natural medicament: A comprehensive review. Crit. Rev. Food Sci. Nutr. 2019, 59, 1433-1455. [CrossRef] 
26. Mehmood, A.; Ishaq, M.; Zhao, L.; Safdar, B.; Rehman, A.U.; Munir, M.; Raza, A.; Nadeem, M.; Iqbal, W.; Wang, C. Natural compounds with xanthine oxidase inhibitory activity: A review. Chem. Biol. Drug Des. 2019, 93, 387-418. [CrossRef]

27. Ishaq, M.; Mehmood, A.; Ur Rehman, A.; Dounya Zad, O.; Li, J.; Zhao, L.; Wang, C.; Hossen, I.; Naveed, M.; Lian, Y. Antihyperuricemic effect of dietary polyphenol sinapic acid commonly present in various edible food plants. J. Food Biochem. 2020, 44, 13111. [CrossRef] [PubMed] 